\title{
Preparation of Magnetic Tunnel Transistors with Double Tunnel Junctions
}

\author{
H. Nakanishi, H. Omae, Y. Fujiwara, M. Jimbo*, T. Kobayashi, S. Shiomi \\ Department of Physics Engineering, Mie Univ., Kurima-machiya-machi 1577, Tsu 514-8507, Japan \\ * Daido Institute of Technology, Takiharu 10-3, Minami-ku, Nagoya 457-8530, Japan
}

\begin{abstract}
Magnetic tunnel transistors (MTTs) with double tunnel junctions were prepared in order to investigate the emitter voltage dependence of a magneto-current (MC). A three-terminal structure was fabricated, using metal shadow masks. It was observed that hot electrons contributed to a collector current. A transfer ratio of over $10^{-3}$ was obtained in an MTT with double tunnel junctions. The MC decreased gradually with increasing emitter voltage. The emitter voltage at which the MC decreased to half its original value was over $1.5 \mathrm{~V}$.
\end{abstract}

Key words: magnetic tunnel transistor, hot electron, tunnel junction, spin valve, transfer ratio

\section{ダブルトンネルジャンクションを用いたマグネティックトンネルトランジスタ}

中西晴久 $\cdot$ 大前春喜 $\cdot$ 藤原裕司 $\cdot$ 神保睦子* - 小林正 - 塩見繁

三重大学物理工学科, 三重県津市栗真町屋町 1577 (广514-8507)

*大同工業大学, 名古屋市南区滝春町 10-5（广 457-8530）

\section{1.はじめに}

スピンバルブトランジスタ(SVT)12)やマグネティックトンネ ルトランジスタ (MTT) ${ }^{3)-6)}$ は半導体と磁性体を組み合わせ た 3 端子素子である. 両者ともに, エミッタ電極からホッ トエレクトロンをベース層に注入する構造になっている. 注入された電子のうち，ベース層内で散乱されず，コレク タ側のショットキー障壁を越えることが出来た電子のみを コレクタ電流として観測し，このコレクタ電流は $300 \%$ 以 上の大きな磁気電流効果 $(\mathrm{MC})$ を示す。しかし，ホットエ レクトロンのみを観測するという原理上，電流透過率（コ レクタ電流のエミッタ電流に対する比率) は非常に小さく, $10^{-5}$ 程度となっている. 電流透過率を増加させる 1 つの方 法として，コレクタ側のバリアをトンネルバリアとする方 法が考えられる。

そこで，本研究ではエミッタバリア，コレクタバリア共 に $\mathrm{AlO}_{\mathrm{x}}$ を用いたダブルトンネルジャンクション $\mathrm{MTT}$ を 作製し，電流透過率および MC のエミッタバイアス依存 性を検討したので報告する。また，本実験で作製した素子 のコレクタバリアの高さが約 $2 \mathrm{eV}$ と高いために, ベース に注入された電子の内，ベース層で散乱されずにコレクタ にトンネルした電子をホットエレクトロンと定義した.

\section{2. 試料作製方法}

試料は dc および rf マグネトロンスパッタ法を用い，熱酸化膜 付 $\mathrm{Si}$ 基板上に作製した．到達真空度は $5 \times 10^{-5} \mathrm{~Pa}$ 以下であ る. $\mathrm{AlO}_{\mathrm{x}}$ 酸化膜は， $6.5 \mathrm{~Pa}$ の純酸素中で $\mathrm{dc}$ 逆スパッタに より作製した。酸化電力はエミッタ, コレクタバリアとも に約 $24 \mathrm{~W}$ であり, 酸化時間はそれぞれ 75 秒と 50 秒である.

試料の膜構成および測定回路図を Fig. 1(a)(b)に示す. 本実験ではFig. 2 に示寸3つの異なる金属マスクを用いて, 3 端子構造を実現した。この時の，エミッターベースおよ びベースーコレクタ接合の面積はそれぞれ，0.4×0.1，
$0.3 \times 0.2 \mathrm{~mm}^{2}$ となる. エミッタ，ベース，コレクタ電極は Fig.1（a)のように構成されており，それぞれ $\mathrm{AlOx}$ 膜によ り絶縁されている。エミッタ側の Co は保磁力を増大させ るため 7), 成膜後, 純酸素中で数秒酸化した.

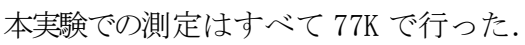

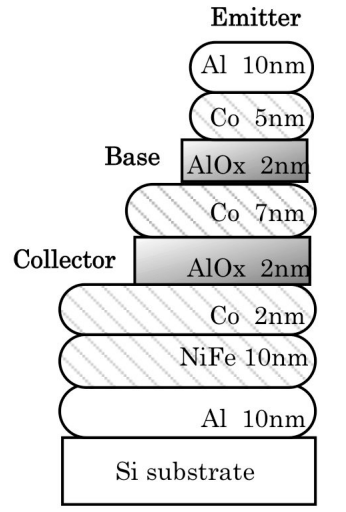

(a)

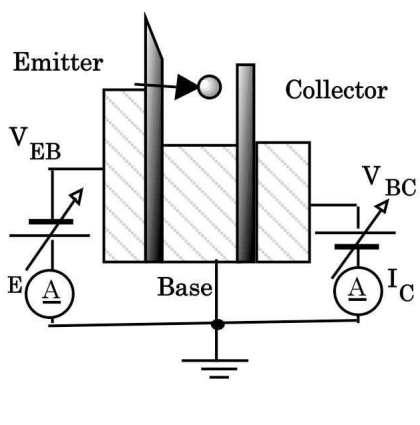

(b)
Fig. 1 Illustrations of (a) sample structures and (b) experimental setup.

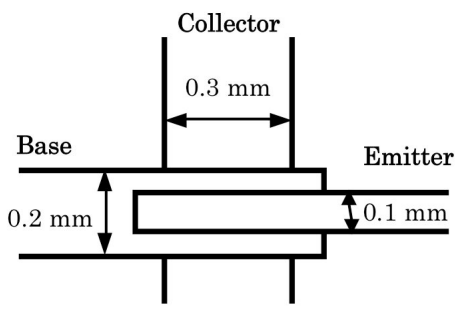

Fig. 2 Arrangement of the metal masks.

\section{3. 実験結果および考察}

Fig. 1(a)の素子に対して，エミッタ-ベース，ベース-コレクタ間 の電流-電圧特性を測定した. 結果を Fig. 3 に示す. Fig.4 (a)(b)に は，それぞれの接合のトンネル磁気抵抗効果（TMR）の測定結 
果を示す.

Fig. 3 より, どちらの接合でも非線形な電流-電圧特性が 得られており，トンネル障壁が形成されていることがわか る. Simmons の式 8)より見積もられるバリア高さと幅は エミッタ側が約 $3 \mathrm{eV}, 1.4 \mathrm{~nm}$, コレクタ側が約 $2.3 \mathrm{eV}, 1.6 \mathrm{~nm}$ であった. Fig.4 (a),(b)はバイアス電圧 $10 \mathrm{mV}$ を印加した測定 結果であり，縦軸を電流值としている，ベースーコレクタ では保磁力差型の TMR ループが確認できるが, ベースエミッタではマイナーループとなっている，これはエミッ 夕側の $\mathrm{Co}$ 成膜後に純酸素中で酸化しているため, $\mathrm{Co}-\mathrm{CoO}$ の反強磁性結合が生じているためである.

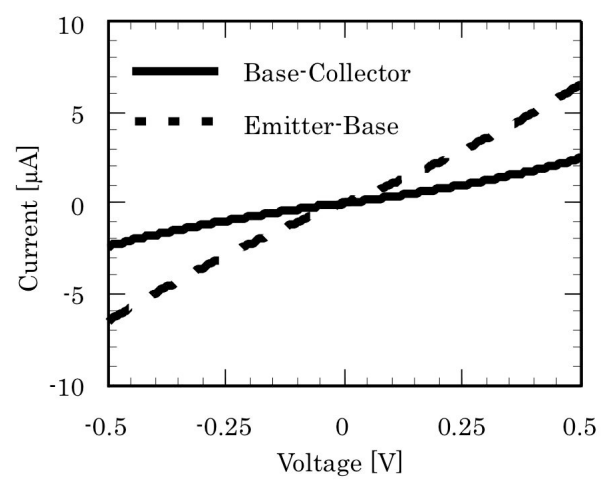

Fig. 3 Current-voltage characteristics for each junction.

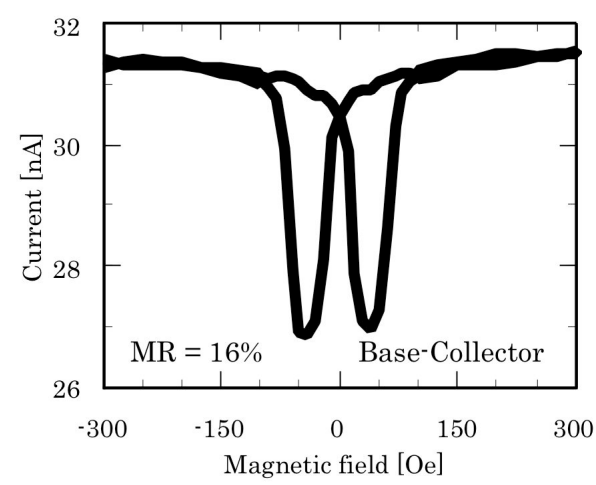

(a)

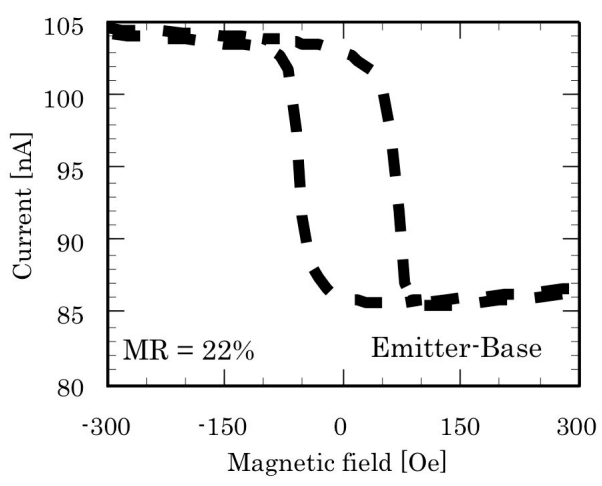

(b)

Fig. 4 TMR loops for (a)base-collector and (b) emitter-base junctions.

次に，今回作製した MTT において, Rodary らが行っ た実験 9) と同様の方法でホットエレクトロンの確認を行っ た．具体的な実験方法は以下の通りである。

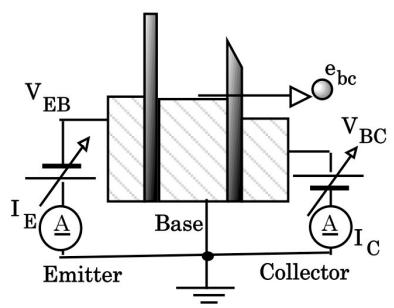

(a)

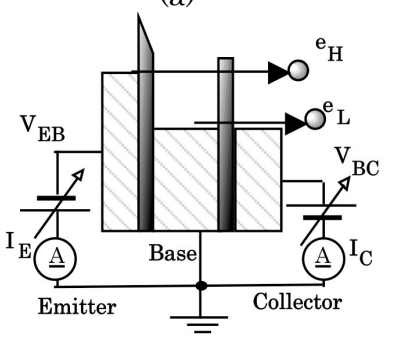

(b)

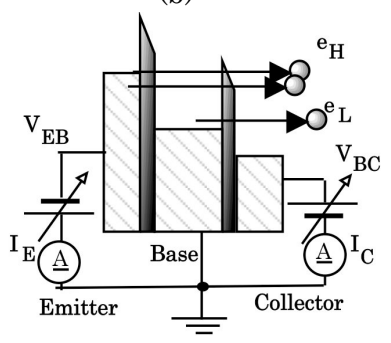

(c)

Fig. 5 Schematic illustrations of the tunneling process.

(1) Fig. 1(b)の回路において $\mathrm{V}_{\mathrm{EB}}=0 \mathrm{~V}$ として， $\mathrm{V}_{\mathrm{BC}}$ を変化 させて，コレクタ電流を測定する．これを I $\mathrm{C} 0$ とする.

$\mathrm{I}_{\mathrm{C} 0}$ の測定は Fig. 5(a)のように, $\mathrm{V}_{\mathrm{EB}}=0 \mathrm{~V}$ のときに $\mathrm{V}_{\mathrm{BC}}$ を変化させる場合に相当する。電圧はコレクタバリア に印加されることになるため, コレクタバリアの電流電圧特性（図中ではトンネルする電子が ebc で表されて いる）のみが現れる.

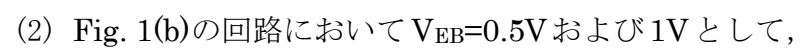
$\mathrm{V}_{\mathrm{BC}}$ を変化させて, 同様にコレクタ電流を測定する.こ れを $\mathrm{I}_{\mathrm{C} 1} ， \mathrm{I}_{\mathrm{C} 2}$ とする. 本実験の素子のベース層の抵抗は $1 \mathrm{k} \Omega$ 以下であるが（エミッタ，コレクタ側の接合抵抗 はそれぞれ約 $100 \mathrm{k} \Omega, 200 \mathrm{k} \Omega$ ） ベース層での電圧降下 を少なくするため $-0.5 \mathrm{~V}<\mathrm{VBC}<0.5 \mathrm{~V}$ とした．このとき， ベースに流れる電流は $40 \mu \mathrm{A}$ 以下であった.

$\mathrm{V}_{\mathrm{EB}}=0.5 \mathrm{~V}$ しくは $1 \mathrm{~V}$ の電圧を印加することは, Fig. 5(b)のように, エミッタ電極からベース層にホットエ レクトロンを注入することに対応している．注入され た電子はベース層で散乱され, ベース電極へ流れるが,

一部は, コレクタバリアをトンネルして, コレクタ電 流となる，そのため，Fig. 5(c)のように VBC を変化さ せた場合, コレクタでは, ベースーコレクタ間の電流-電圧 特性に加えて, エミッタからコレクタへ向かう電子の分だけ 電流が増加することになる.

(3) I I 1 - IC0 および I $\mathrm{C} 2_{\mathrm{C}}$ - I $\mathrm{C} 0$ を求める.

この差分の電流にホットエレクトロンが含まれてい ると考えられる. 
これらの実験結果を Fig. 6 および Fig. 7 に示す.

Fig. 6 では I $\mathrm{C} 0 ， \mathrm{I}_{\mathrm{C} 1}, \mathrm{I}_{\mathrm{C} 2}$ すべて非線形な電流-電圧特性 を示していることがわかる. $\mathrm{I}_{\mathrm{C} 0}$ において, $\mathrm{V}_{\mathrm{BC}}=0.5 \mathrm{~V}$ の時 の電流值は約 $2.4 \mu \mathrm{A}$ であり, Fig. 3 で示されているべースコレクタ間の電流-電圧特性から得られる值とほぼ同じ值になって いる．また， $\mathrm{I}_{\mathrm{C} 0}$ と $\mathrm{I}_{\mathrm{C} 2}$ を比べると， $\mathrm{I}_{\mathrm{C} 2}$ がどの電圧でも大 きくなっており， $\mathrm{V}_{\mathrm{EB}}$ により, エミッタ電極からベース層 へ注入された電子が，コレクタ電極へ到達していることが

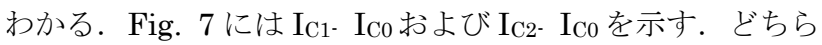
も, 電流の差が一定にはならず, $\mathrm{V}_{\mathrm{BC}}$ の増加とともに非線 形に増加している.

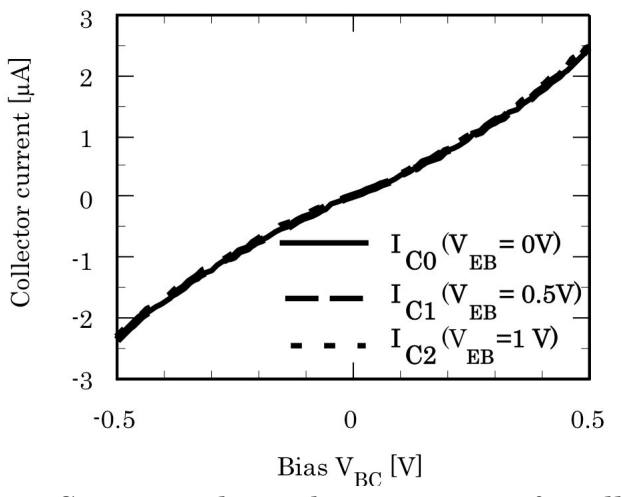

Fig. 6 Current-voltage characteristics of a collector barrier for emitter-base voltages.

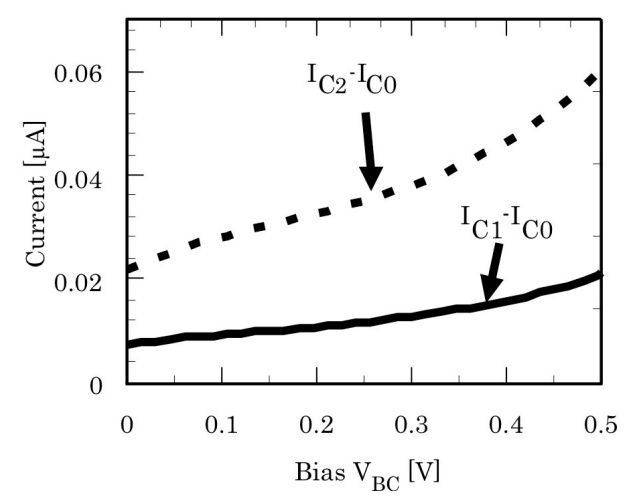

Fig. 7 Hot electron contribution to the collector current.

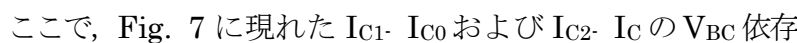
性を考察するため, エミッタ電極からコレク夕電極へ向かう電 子を 2 種類のエネルギーにわけて考える. 1 つはベース層でほと んどエネルギーを失って, ベース層のフェルミ準位からコレクタ 電極へトンネルする電子. もう 1 つは, ベース層で散乱されず, 高いエネルギーを持ったままコレクタ電極へトンネルする電子で ある. これらは Fig. 5(b)(c)において $\mathrm{e}_{\mathrm{H}}, \mathrm{e}_{\mathrm{L}}$ として表されている.

$\mathrm{V}_{\mathrm{BC}}=0 \mathrm{~V}$ の状態 Fig. 5(b)では, ベース層で散乱されてほ とんどエネルギーを失った後，コレクタ電極へトンネルす る電子 e L と, ベース層で散乱されず, 高いエネルギーを 持ったままでコレクタ電極へ到達する電子 $\mathrm{e}_{\mathrm{H}}$ が存在する. この状態で, ある一定の正のバイアスを $\mathrm{V}_{\mathrm{BC}}$ を印加すると, Fig.5 (c)で示されるように，コレクタバリアの形状が変化 するため. $\mathrm{e}_{\mathrm{H}}$ が増加し, その結果, コレクタ電流が増加
すると考えることができる，(図中ではバイアス電圧 $V_{\mathrm{BC}}$ に よって流れる電子 $\mathrm{e}_{\mathrm{bc}}$ は省略されている.） V $\mathrm{VBC}$ を大きくしてい けば， $\mathrm{e}_{\mathrm{H}}$ はさらに増加すると考えられ，その増加はエミ ッタ電極から注入される電子のエネルギー分布に対応する と考えることができる．したがって，Fig. 7 に現れている I $\mathrm{I}_{\mathrm{C} 1}$

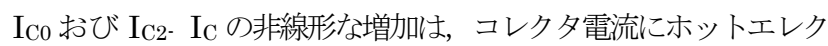
トロンが含まれていることを示していると考えることが出来る.

コレクタ電流の $\mathrm{MC}$ ループを Fig. 8 に示す. この時 $\mathrm{V}_{\mathrm{EB}}=0.1[\mathrm{~V}]$, $\mathrm{V}_{\mathrm{BC}}=0 \mathrm{~V}$ である, 図中にエミッタ, ベース, コレクタ各電極の磁 化状態を示している. エミッタ電極の Co の保磁力が大きいため に, 今回の実験の範囲内では磁化が反転せず， 4 つの磁化状態を 取っていることがわかる. MC の見積もりは-300 Oe の磁界印加 時の電流值 $I_{C P}$ と +70 Oe の磁界印加時の電流值 $I_{\mathrm{CAP}}$ 用いて,

$$
\mathrm{MC}=\left(\mathrm{I}_{\mathrm{CP}}-\mathrm{I}_{\mathrm{CAP}}\right) / \mathrm{I}_{\mathrm{CAP}} \times 100[\%]
$$

として見積もることとした，見積もられた MC は約 18\%であっ た. コレクタバリアとしてショットキー障壁を用いた MTT では 200\%以上の MC が得られる゙，今回の MTT では 1 林小さい值 となった.

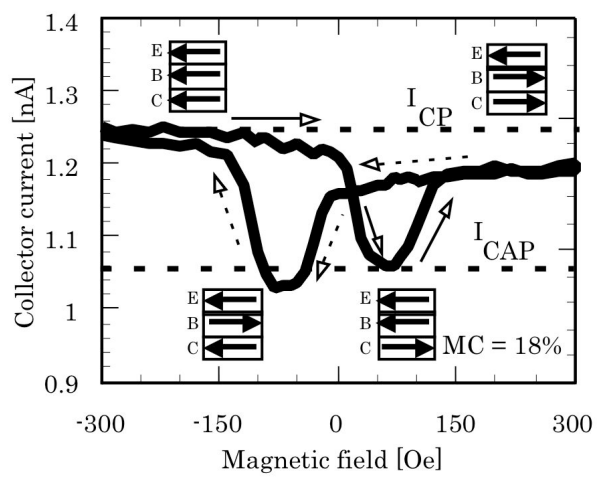

Fig. 8 Typical magneto-current loop of an MTT with double tunnel junctions.

電流透過率（コレクタ電流のエミッタ電流に対する比 : $\mathrm{I}_{\mathrm{C}} / \mathrm{I}_{\mathrm{E}}$ ) およびMCのエミッタ電圧(VEB 依存性を Fig. 9, 10 に示す. Fig. 9 の実線は-300 Oe の磁界を印加して測定したもの，破線は+70 Oe の磁界のときのものである. この時, $\mathrm{V}_{\mathrm{BC}}=0 \mathrm{~V}$ である. 電流透過 率は $\mathrm{V}_{\mathrm{EB}}=0.1 \mathrm{~V}$ 以上でほとんど一定の值 $\left(1.2 \times 10^{-3}\right)$ となってい ることがわかる.

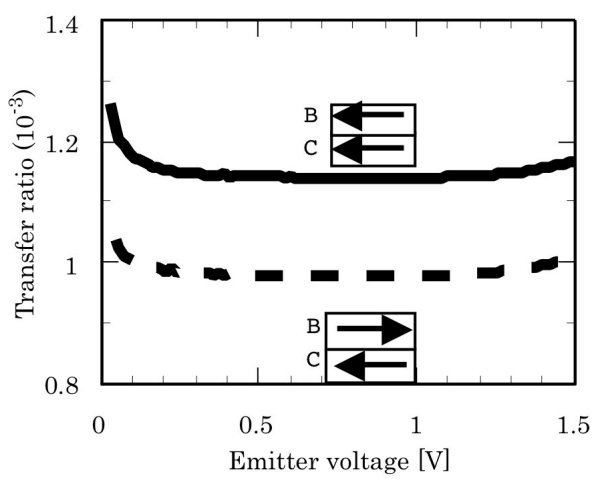

Fig. 9 Emitter-base voltage dependence of transfer ratios. 
Fig. 10 の MC は Fig. 9 より見積もったものである. 参考のた め, 同じ試料を室温で測定したものも同時に示しておく．MC は 最大約 $20 \%$ 程度であり, エミッタ電圧の増加とともに減している. $\mathrm{V}_{\mathrm{EB}}=1.5 \mathrm{~V}$ のときに MC は $15 \%$ 以上の值を示しており, 通常の TMR 素子よりも, バイアス電圧依存性が小さいことがわかる. そこで, $\mathrm{MC}$ の值が半分になる電圧 $\mathrm{V}_{1 / 2}$ を見積もってみると, $77 \mathrm{~K}$ で $1.5 \mathrm{~V}$ 以上，室温でも $1.0 \mathrm{~V}$ 以上になる.

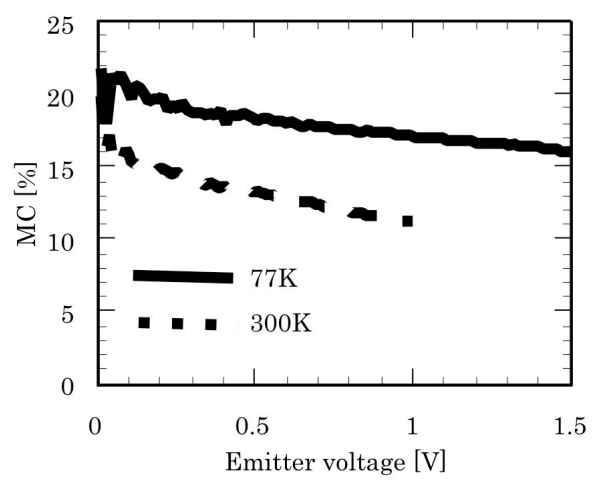

Fig. 10 Emitter-base voltage dependence magneto- current.

この MTT のエミッタ電圧依存性を考察するために，Fig. 11 の 試料を用いて，エミッタ，コレクタそれぞれから電子を注入した 場合の MC の電圧依存性を測定した. 測定回路と測定結果を Fig. 12 に示す. 実線はエミッタ (非磁性電極) から電子を注入した時 のコレクタ電流の $\mathrm{MC}$ であり, 横軸は E-B 間電圧に対応する. また, 破線はコレクタ (磁性電極) から電子を注入した時のエミ ッタ電流の MC であり, 横軸は C-B 間電圧に対応する. 破線の 電圧依存性は通常の TMR のバイアス依存性と同様の傾向を示し ており， $\mathrm{MC}$ の值が半分になる電圧は $0.5 \mathrm{~V}$ 以下となっている. 一方，エミッタ (非磁性) 側から注入した場合, MC の值が半分 になる電圧は Fig. 10 のように比較的大きな值を示している.

エミッタ (非磁性) 側からホットエレクトロンを注入した場合, $\mathrm{MC}$ はベース層でのバルク散乱と, ベースからコレクタへの TMR 効果の大きさに依存すると考えることができる.コレクタから注 入した場合もべース層内でのバルク散乱の効果は同じであると考 えることができるので, Fig. 10 のエミッタ電圧が高い所での比較 的大きな MC はホットエレクトロンによる TMR 効果によって生 じていると考えることができる.

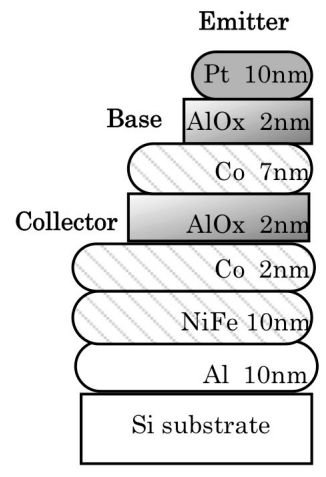

Fig. 11 Sample structure of another type of MTT.

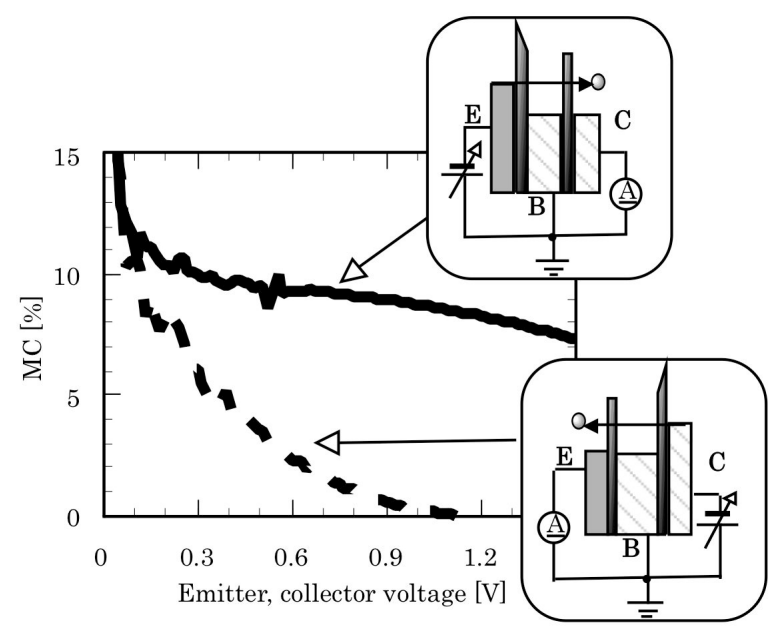

Fig. 12 Emitter, collector voltage dependence of the magnetocurrent for the collector and emitter injections.

\section{4. まとめ}

エミッタバリア，コレクタバリア共に $\mathrm{AlO}_{\mathrm{x}}$ トンネルバ リアを用いた MTT を作製し, その電流透過率, MC のエ ミッタ電圧 $\left(\mathrm{V}_{\mathrm{EB}}\right)$ 依存性を検討した.

$\mathrm{V}_{\mathrm{EB}}$ を一定として, ベースーコレクタ間の電流-電圧特性を測 定した結果，ホットエレクトロンがコレクタ電流に含まれている 可能性があることがわかった.

電流透過率のエミッタ電圧依存性では, 電圧を印加する とすぐに透過率は減少するが, $0.1 \mathrm{~V}$ 以上ではほとんど変 化しないことが分かった．この時の值は $1.2 \times 10^{-3}$ であり， 従来の MTTに比べて 1 桁大きな值となった.

MC のエミッタ電圧依存性は通常の TMR 素子のバイア ス依存性よりも小さく, $\mathrm{MC}$ の值が半分となるエミッタ電 圧は $1.5 \mathrm{~V}$ 以上になる. この高い電圧範囲での $\mathrm{MC}$ は, 主に, ベ 一スからコレクタヘトンネルするホットエレクトロンによる TMR の寄与であると考えることができる.

\section{References}

1) D. J. Monsma, J. C. Lodder, J. A. Popma and B. Dieny, Phys. Rev. Lett. 74, 5260 (1995).

2) P. S. A. Kumar, R. Jansen, O. M. J. van't Erve, R. Vlutters, P. de Haan and J. C. Lodder, J. Magn. Magn. Mater. 214, L1 (2000).

3) K. Mizushima, T. Kinno, T. Yamauchi and K. Tanaka, IEEE Trans. Magn. 33, 3500 (1997).

4) S. Dijken, X. Jiang and S. S. P. Parkin, Appl. Phys. Lett. 80, 3364 (2002)

5) T. Hirose, Y. Fujiwara, M. Jimbo, T. Kobayashi, S. Shiomi and M. Masuda, Jpn. J. Appl. Phys. 43, 2479 (2004).

6) T. Hirose, Y. Fujiwara, M. Jimbo, T. Kobayashi and S. Shiomi, J. Magn. Magn. Mater. 286, 124 (2005).

7) W. H. Meiklejohn and C. P. Bean, Phys. Rev. 102, 1413 (1956).

8) J. G. Simmons, J. Appl. 34, 1793 (1963).

9) G. Rodary, M. Hehn, T. Dimopoulos, D. Lacour, J. Bangert, H. Jaffrés, F. Montaigne, F. Nguyen van Dau, F. Petroff, A. Schuhl and J. Wecker, J. Magn. Magn. Mater. 290-291, 1097 (2005).

2005年10月19日受理，2005年12月5日再受理，2006年1月16日採録 